\title{
Narrow flower specialization in two European bee species of the genus Colletes (Hymenoptera: Apoidea: Colletidae)
}

\author{
ANDREAS MÜLLER ${ }^{1}$ and Michael KUHLMANN ${ }^{2}$ \\ ${ }^{1}$ Institute of Plant Sciences, Applied Entomology, Swiss Federal Institute of Technology (ETH), Clausiusstrasse 25/NW, CH-8092 \\ Zurich, Switzerland; e-mail: andreas.mueller@ipw.agrl.ethz.ch \\ ${ }^{2}$ University of Münster, Institute of Landscape-Ecology, Robert-Koch-Str. 26, D-48149 Münster, Germany; \\ e-mail:kuhlmmi@uni-muenster.de
}

Key words. Apoidea, Colletidae, Colletes, Boraginaceae, Cynoglottis, flower specialization, monolectic, oligolectic, distribution, pollen collection, morphological adaptation

\begin{abstract}
Colletes anchusae Noskiewicz, 1924 and C. wolfi Kuhlmann, 1999 (Colletidae) are closely related bee species with vicariant distributions, the former occurring in east and southeast Europe and Turkey, the latter restricted to the Italian peninsula. Microscopical analysis of scopal pollen revealed that in Europe both species are monolectic collecting pollen exclusively from flowers of Cynoglottis barrelieri (All.) Vural \& Kit Tan (Boraginaceae). In Turkey, C. anchusae possibly visits also Cynoglottis chetikiana Vural \& Kit Tan. The distributions of the two bee species and of Cynoglottis coincide. The females of both Colletes species are equipped with stout, curved bristles on their foretarsi used for scraping pollen out of the narrow flower tube of Cynoglottis. Compared to other European species of Colletes the foretarsi of $C$. anchusae and $C$. wolfi are shortened, presumably an adaptation to the short corolla tube of their host plant.
\end{abstract}

\section{INTRODUCTION}

The closely related bee species Colletes anchusae Noskiewicz, 1924 and Colletes wolfi Kuhlmann, 1999 are unique among palaearctic Colletes in that their females have simple, non bifurcate claws and strongly modified foretibia (Noskiewicz, 1936; Kuhlmann, 1999). In addition to the peculiarly shaped tibia the foretarsi of the females of both species are beset with stout, curved bristles distinctly different from the tarsal hairs of other Colletes bees. The females of four North American Calliopsis species (Andrenidae), the Australian Leioproctus macmillani (Colletidae) and the Eurasian Colletes nasutus (Colletidae) have similar tarsal bristles (Shinn, 1967; Houston, 1991; Müller, 1995). In these bee species, the specialized bristles serve to scrape pollen out of the narrow flower tubes of Verbena (Verbenaceae), Astroloma (Epacridaceae) and Anchusa (Boraginaceae), respectively.

There is little doubt that the females of $C$. anchusae and $C$. wolf $i$ use the tarsal bristles to extract pollen from flowers with hidden anthers. Indeed, in Hungary and the Ukraine $C$. anchusae was repeatedly observed on flowers of Anchusa barrelieri (All.) Vitman, a member of the Boraginaceae with narrow flower tubes (Noskiewicz, 1924, 1936; Móczár, 1961). A. barrelieri differs from other Anchusa species in having distinctly smaller pollen grains and a short corolla tube (Vural \& Kit Tan, 1983). Because of these differences Vural \& Kit Tan (1983) put A. barrelieri in its own genus, Cynoglottis. Recently, a second Cynoglottis species, C. chetikiana Vural \& Kit Tan, was described from Turkey (Vural \& Kit Tan, 1983).

The aim of this study was to examine the host plant spectrum of $C$. anchusae and $C$. wolfi, to compare the distributions of these two bee species with that of their host plants and to analyze potential adaptations of bee morphology to flower structure.

\section{MATERIALS AND METHODS}

\section{Pollen sources}

To assess the pollen plants of $C$. anchusae and $C$. wolfi we analyzed the scopal contents of females from museum and private collections by light microscopy using the method outlined by Westrich \& Schmidt (1986). We identified the pollen grains at a magnification of $400 \times$ and $1000 \times$ with the aid of Clarke (1980), the literature cited in Westrich \& Schmidt (1986) and a reference collection containing the pollen of nearly all European genera of the Boraginaceae, including Cynoglottis.

C. anchusae and C. wolfi are among the rarest Colletes species in Europe. Though all available material was examined only 13 females each of $C$. anchusae and $C$. wolf $i$ had pollen in their scopa. These 26 bee specimens were collected at 15 different localities. The pollen samples from $C$. anchusae originate from Macedonia ( 1 sample), Bulgaria (1) and the Turkish provinces of Antalya (1), Konya (2), Adana (1), Nevsehir (2) and Erzincan (5), the samples from $C$. wolf $i$ from the Italian provinces of Piemonte (8), Toscana (1), Umbria (2) and Abruzzo (2).

\section{Distribution}

The distribution of the genus Cynoglottis was clarified with the aid of regional, national and European floras. For details regarding habitat and flowering time Davis (1978, 1988), Pignatti (1982), Shishkin (1974), Strid \& Kit Tan (1991) and Vural $\&$ Kit Tan (1983) were consulted.

Information on the distribution and flight period of $C$. anchusae and C. wolfi were extracted from Noskiewicz (1924, 1936) and the Colletes data bank of M. Kuhlmann (unpublished).

\section{Bee morphology and flower structure}

To examine the structure of the flowers of $C$. barrelieri herbarium specimens were soaked in water.

To estimate the fit between leg length and corolla depth the relative length of the foreleg of $C$. anchusae and $C$. wolf $i$ was compared with that of 16 other European and North African 


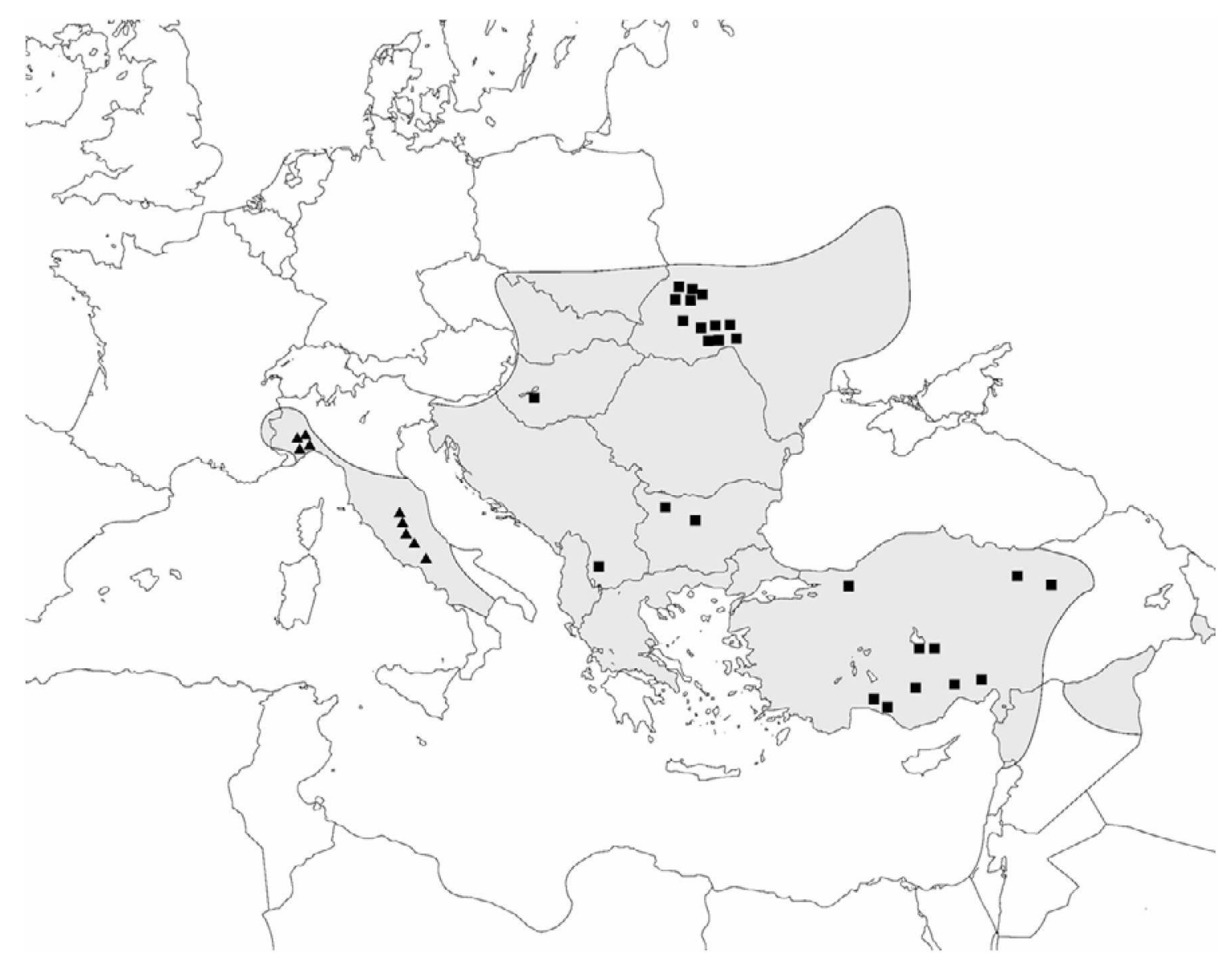

Fig. 1. Distribution of Cynoglottis (shaded) and localities for Colletes anchusae (squares) and C. wolfi (triangles) in Europe and Asia Minor.

Colletes species, each belonging to another species group (see Kuhlmann, 2000), by calculating the ratio of leg length to forewing length. Forewing length was used as a measure of body size. The lengths of femur, tibia and tarsus (up to the insertion of the claws), and forewing (along the anterior margin) were measured under a dissecting microscope to the nearest $1 / 20 \mathrm{~mm}$. For this nine females of $C$. anchusae, ten females of $C$. wolfi and two females each of $C$. albomaculatus (Lucas, 1849), C. cunicularius (Linnaeus, 1761), C. daviesanus Smith, 1846, C. formosus Pérez, 1895, C. gallicus Radoszkowski, 1891, C. hederae Schmidt \& Westrich, 1993, C. hylaeiformis Eversmann, 1852, C. impunctatus Nylander, 1852, C. lacunatus Dours, 1872, C. maidli Noskiewicz, 1936, C. marginatus Smith, 1846, C. meyeri Noskiewicz, 1936, C. mlokossewiczi Radoszkowski, 1891, C. moricei Saunders, 1904, C. nasutus Smith, 1853 and C. nigricans Gistel, 1857 were selected.

\section{RESULTS}

\section{Pollen sources}

The pollen samples from both $C$. anchusae and $C$. wolfi consisted of exactly the same pollen type. At a magnification of $1000 \times$, the pollen grains in the 26 samples could not be distinguished from a reference pollen sample of $C$. barrelieri.

\section{Distribution}

C. barrelieri occurs from Italy eastwards to Turkey and Syria, and northwards to the Ukraine and Russia (Fig. 1). The distribu- tion is split into two parts, a western part covering Italy and an eastern part ranging from Slovenia eastwards. C. chetikiana, the second species of the genus, is endemic to north, central and south Anatolia. In Turkey, the distributions of the two Cynoglottis species partially overlap. Both species grow on dry rocky slopes, stony pastures, fallow fields and open coniferous forest, mostly on limestone. Depending on the altitude the flowering time is May to July.

C. wolfi and C. anchusae show a vicariant distribution (Fig. 1). C. wolf $i$ is confined to Italy whereas $C$. anchusae is found in east and southeast Europe and Turkey. All known localities of the two Colletes species fall within the distribution area of Cynoglottis. Collection records date from 7 May to 28 July ( $\mathrm{n}=$ 24) for C. anchusae and from 27 May to 19 July $(\mathrm{n}=25)$ for $C$. wolfi.

\section{Bee morphology and flower structure}

The corolla of $C$. barrelieri is blue to bluish-violet. The limb is almost flat, 6-9 mm across, with rounded lobes (Fig. 2). The narrowly campanulate tube is short, measuring 1.0 to $1.5 \mathrm{~mm}$ in depth and $2.0 \mathrm{~mm}$ in diameter. At its apex the tube is narrowed by five whitish faucal scales, which protrude slightly from the tube. The anthers are hidden under the hairy scales and reach the base of the scales. The style is included and about half as long as the tube.

The forelegs of both C. anchusae and C. wolfi are modified in two ways. The slightly curved tibia is on its outer surface distinctly concave and hairless (Fig. 3) and the basitarsus is beset 


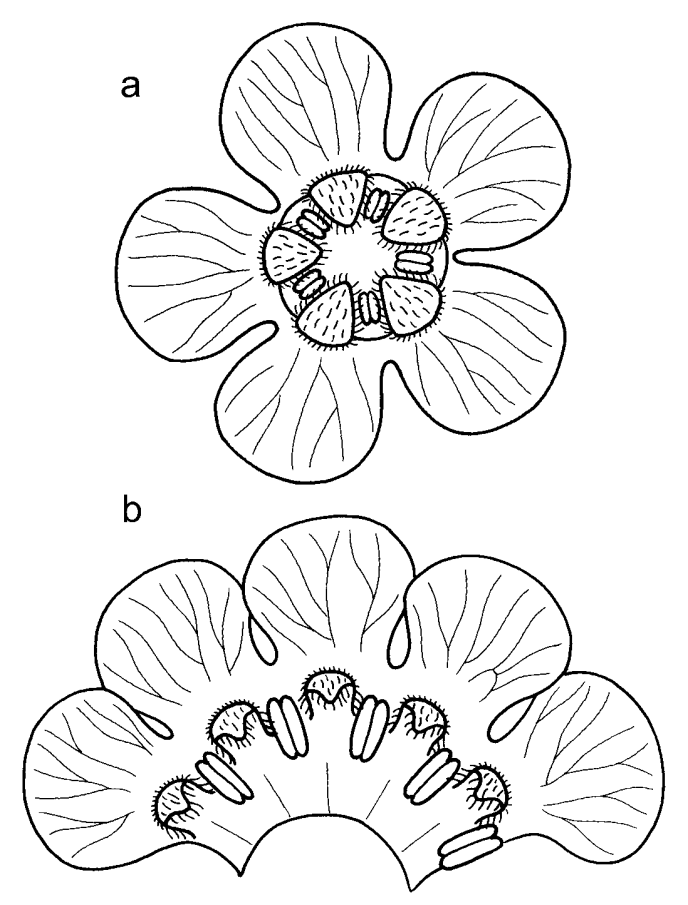

Fig. 2. Cynoglottis barrelieri: corolla from above (a) and dissected (b). $7 \times$ natural size.

with stout, curved bristles on its outside and along its longitudinal borders (Figs 4-5). The same type of curved bristles are found on tarsal segments 2 to 4 . The total length of the foretarsus (without claws) is 1.3 to $1.4 \mathrm{~mm}$, the bristle bearing part is about $1 \mathrm{~mm}$ long.

The tarsus of the foreleg of $C$. anchusae and $C$. wolfi is significantly shorter relative to body size (mean $=0.191, \mathrm{~s}=0.005$, $\mathrm{t}=-13.854, \mathrm{p}<0.0001, \mathrm{n}=19)$ compared to the other Colletes species (mean $=0.224, \mathrm{~s}=0.010, \mathrm{n}=32$ ). In contrast, the total relative length of the foreleg, comprising tarsus, tibia and femur, does not significantly differ between $C$. anchusae and $C$. wolfi (mean $=0.600, \mathrm{~s}=0.010, \mathrm{t}=-1.970, \mathrm{p}=0.055, \mathrm{n}=19)$ and the other Colletes species (mean $=0.616, \mathrm{~s}=0.033, \mathrm{n}=32$ ).

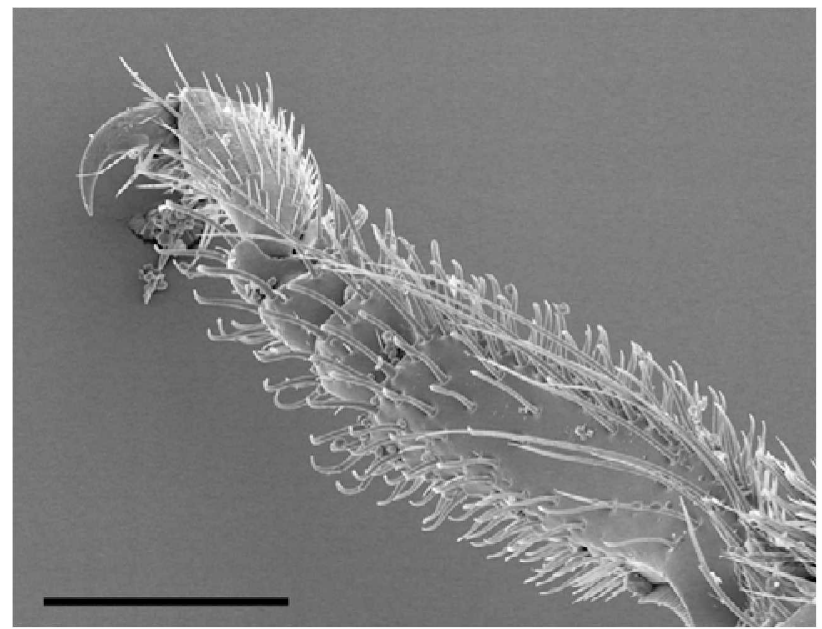

Fig. 4. Colletes wolfi: female left foretarsus seen from the outside. $($ Scale bar $=300 \mu \mathrm{m})$

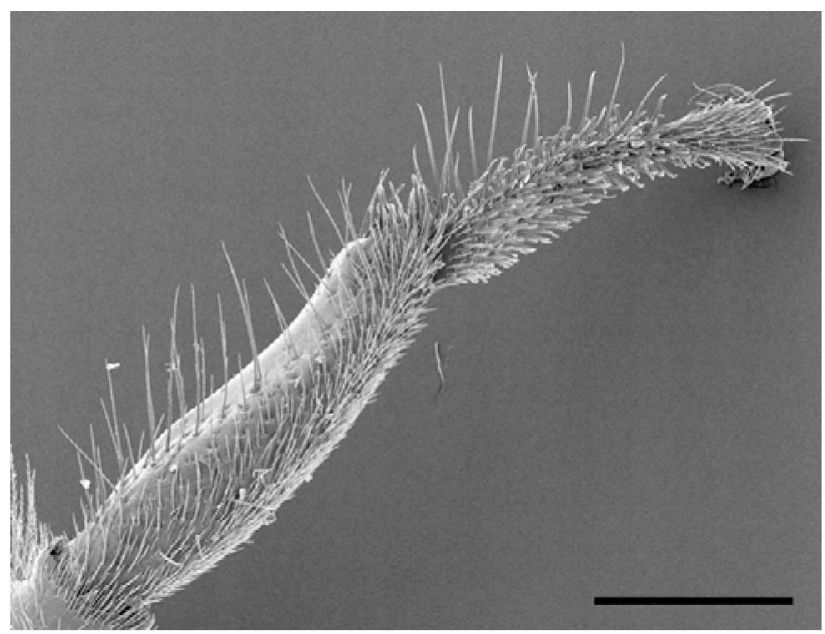

Fig. 3. Colletes wolf $i$ : female left foreleg seen from above. $($ Scale bar $=500 \mu \mathrm{m})$

\section{DISCUSSION}

\section{Pollen sources}

All scopal pollen from both $C$. anchusae and C. wolfi consisted only of Cynoglottis pollen suggesting an exclusive preference for this boraginaceous plant. The 26 pollen samples originated from 15 different localities scattered over most of the distribution areas of the two Colletes species. This strong specialization is corroborated by observations made in the Ukraine where C. anchusae is quite common and collects pollen exclusively from Cynoglottis barrelieri (Noskiewicz, 1924, 1936). In Hungary, $C$. anchusae is also believed to be a specialist of this plant species (Móczár, 1961). The close match in the distributions of the bees and Cynoglottis is a further indication of this intimate relationship as is the coincidence of the flowering time of Cynoglottis with the flight period of the bees.

C. barrelieri is the only Cynoglottis species in Europe. In Turkey, a second Cynoglottis species occurs. C. chetikiana differs from C. barrelieri in its distinctly longer corolla tube (Vural $\&$ Kit Tan, 1983). Whether $C$. anchusae also visits flowers of $C$. chetikiana in Turkey is an open question.

C. anchusae and C. wolfi are not the only European species of Colletes with very restricted flower preferences. C. nasutus seems to visit only Anchusa officinalis (Boraginaceae), C. sier-

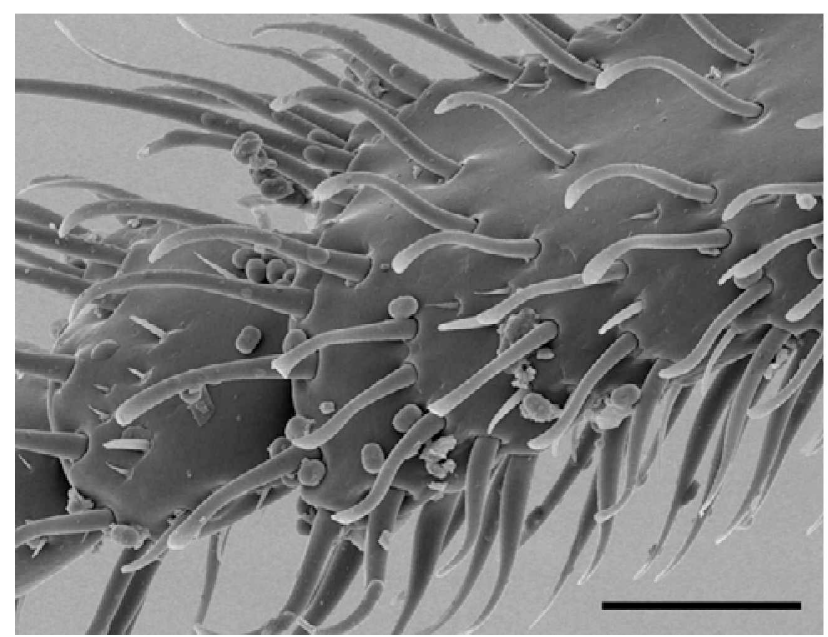

Fig. 5. Colletes wolfi: Apex of basitarsus and second tarsal segment seen from the outside. (Scale bar $=90 \mu \mathrm{m})$ 
rensis is a likely monolege of Odontites viscosa (Scrophulariaceae), Colletes hederae restricts pollen harvesting to Hedera helix (Araliaceae), C. punctatus is presumed to collect pollen exclusively from Nigella (Ranunculaceae), C. graeffei probably visits only Allium (Liliaceae) and C. hylaeiformis is specialized to Eryngium (Apiaceae) (Noskiewicz, 1936; Westrich, 1990; Schmidt \& Westrich, 1993; Westrich \& Amiet, 1996; Mader, 1999; own observations). Though the percentage of oligolectic species might be higher in the genus Colletes than in other bee genera in Europe (Westrich, 1990; Westrich, 2001) not all European Colletes species are narrow pollen specialists C. floralis is highly polylectic (Westrich, 2001) and the microscopical analysis of several hundred pollen samples from many western palaearctic Colletes species revealed that in several species groups polylectic species occur (Müller \& Kuhlmann, unpublished).

\section{Distribution}

C. wolfi and C. anchusae differ morphologically only slightly (Kuhlmann, 1999) indicating a recent separation of these two species. This is compatible with the hypothesis that populations of the ancestor of the two species survived the ice age in at least two refuges, one in Italy and another in southeast Europe or Turkey, from where they spread northwards after the end of the last glacial period. The gap in the distribution area of their host plant might then have prevented the two populations from coming into contact again.

Both $C$. anchusae and $C$. wolf $i$ are considered to be very rare. However, their flower specialization might account for why these bees are so rarely collected in the field. We expect them to be much more widespread occurring wherever Cynoglottis grows.

\section{Bee morphology and flower structure}

Thirteen Central European species of bees belonging to four families and five genera are known to have evolved stout, curved bristles either on the forelegs or on the proboscis (Müller, 1995). In all these species the specialized bristles serve to extract pollen from the flowers of plants whose anthers are hidden in narrow tubes. Similar morphological specializations are also known in bees from outside Europe (Shinn, 1967; Thorp, 1979, 2000; Houston, 1991). Here too, the modified hairs are a tool for removing pollen from narrow flower tubes. Though field observations are still lacking both C. anchusae and $C$. wolfi are thought to use the specialized bristles on their foretarsi to harvest pollen from Cynoglottis. Females of C. nasutus are known to insert both forelegs simultaneously into a flower tube of Anchusa officinalis before extracting pollen from the hidden anthers with repeated upward and downward movements of their forelegs (Müller, 1995). Females of C. anchusae and C. wolfi probably collect pollen in much the same way.

The function of the modified female tibia in C. anchusae and $C$. wolf i is obscure. The tibial curvature might enable the bees to bring the tarsi of their forelegs closer together and in a parallel position before they are simultaneously inserted into the narrow entrance of a flower.

In both $C$. anchusae and $C$. wolfi the development of hooked bristles on the foretarsus is accompanied by a shortening of the foretarsus. The tarsal length is similar to the tube length of $C$. barrelieri. Consequently, the shortening of the foretarsus might be an adaptation to the short corolla tube of the host plant allowing the bees to use the total length of their tarsi to scrape pollen out of the flower. In contrast to $C$. anchusae and $C$. wolfi forelegs, head and proboscis of $C$. nasutus are distinctly lengthened compared to other European Colletes species, doubtless an adaptation for collecting pollen and nectar from the deep tubular flowers of Anchusa officinalis, which are 7 to $10 \mathrm{~mm}$ long (Müller, 1995).

ACKNOWLEDGEMENTS. We thank Slavica Katulic for compiling information on the distribution of Cynoglottis, Dr. Reto Nyffeler (Institute for Systematic Botany, University of Zurich) for the permission to work in the herbarium, Urs Jauch (Institute for Botany, University of Zurich) for help with the scanning electron microscope, Fritz Gusenleitner (Oberösterreichisches Landesmusum, Linz) and Guido Pagliano (Museo Regionale di Scienze Naturali, Torino) for loan of specimens from collections under their curatorship, Dr. Kathrin Tschudi-Rein (ETH Zurich) for correcting the English and Prof. Dr. Silvia Dorn (ETH Zurich), Dr. Jörg Samietz (ETH Zurich) and three reviewers for helpful comments on earlier drafts of the manuscript.

\section{REFERENCES}

Clarke G.C.S. 1980: Boraginaceae. In: Punt W. \& Clarke G.C.S. (eds): The Northwest European Pollen Flora. Vol. 2. Elsevier, Amsterdam, pp. 59-102.

Davis P.H. 1978: Flora of Turkey and the East Aegean Islands. Vol. 6. University Press, Edinburgh, $825 \mathrm{pp}$.

Davis P.H. 1988: Flora of Turkey and the East Aegean Islands. Vol. 10. University Press, Edinburgh, 590 pp.

Houston T.F. 1991: Two new and unusual species of the bee genus Leioproctus Smith (Hymenoptera: Colletidae), with notes on their behaviour. Rec. West. Austral. Mus. 15: 83-96.

Kunlmann M. 1999: Colletes wolfi spec. nova from Italy, and lectotype designation for palaearctic bees of the genus Colletes Latr., with notes on new homonymies and synonymies (Hymenoptera: Apidae: Colletinae). Linz. Biol. Beiträge 31: $71-81$.

Kunlmann M. 2000: Katalog der paläarktischen Arten der Bienengattung Colletes Latr., mit Lectotypenfestlegungen, neuer Synonymie und der Beschreibung von zwei neuen Arten (Hymenoptera: Apidae: Colletinae). Linz. Biol. Beiträge 32: 155-193.

MADER D. 1999: Geologische und Biologische Entomoökologie der Rezenten Seidenbiene Colletes. Band 1. Logabook, Köln, $807 \mathrm{pp}$.

MóczÁr M. 1961: Revision, Faunakatalog und ethologische Angaben über die Arten der Gattung Colletes Latr. (Fam. Colletidae II., Cat. Hym. XIX). Folia Entomol. Hungar., N.S. 14: 403-412. [in Hungarian, German abstr.]

MÜLLER A. 1995: Morphological specializations in Central European bees for the uptake of pollen from flowers with anthers hidden in narrow corolla tubes (Hymenoptera: Apoidea). Entomol. Gener. 20: 43-57.

NoskIEWICz J. 1924: Zwei neue Bienenarten aus Polen. Kosmos 49: 118-127. [in Polish, German abstr.]

Noskiewicz J. 1936: Die palearktischen Colletes-Arten. Pr. Nauk. Wyd. Tow. Nauk, Lwow 3: 1-531.

Pignatti S. 1982: Flora d'Italia. Vol. 2. Edagricole, Bologna, $732 \mathrm{pp}$.

Schmid K. \& Westrich P. 1993: Colletes hederae n. sp., eine bisher unerkannte, auf Efeu (Hedera) spezialisierte Bienenart (Hymenoptera: Apoidea). Entomol. Zeitschr. 103: 89-112.

SHINN A.F. 1967: A revision of the bee genus Calliopsis and the biology and ecology of C. andreniformis (Hymenoptera: Andrenidae). Kans. Univ. Sci. Bull. 46: 876-891.

SHISHKIN B.K. 1974: Flora of the U.S.S.R. Vol. 19 (Tubiflorae). Israel Program for Scientific Translations, Jerusalem, $556 \mathrm{pp}$.

Strid A. \& Kit TAN 1991: Mountain Flora of Greece. Vol. 2. University Press, Edinburgh, 974 pp. 
ThORP R.W. 1979: Structural, behavioral, and physiological adaptations of bees (Apoidea) for collecting pollen. Ann. Miss. Bot. Garden 66: 788-812.

Thore R.W. 2000: The collection of pollen by bees. Plant Syst. Evol. 222: 211-223.

VuRAL M. \& KIT TAN 1983: New taxa and records from Turkey. Notes RBG Edinb. 41: 65-76.

Westrich P. 1990: Die Wildbienen Baden-Württembergs. Vol. 1 and 2. Ulmer Verlag, Stuttgart, $972 \mathrm{pp}$.
Westrich P. 2001: Zum Pollensammelverhalten der Seidenbiene Colletes floralis Eversmann 1852 (Hymenoptera: Apidae). Linz. Biol. Beiträge 33: 519-525.

Westrich P. \& AMiET F. 1996: Der taxonomische Status von Colletes sierrensis Frey-Gessner 1901 mit Beschreibung des noch unbekanten Männchens (Hymenoptera, Apidae). Linz. Biol. Beiträge 28: 1161-1167.

Westrich P. \& Schmid K. 1986: Methoden und Anwendungsgebiete der Pollenanalyse bei Wildbienen (Hymenoptera Apoidea). Linz. Biol. Beiträge 18: 341-360.

Received February 12, 2003; revised May 7, 2003; accepted June 9, 2003 